\title{
A Comparative Analysis of Feminist Thought In Poems of Maya Angelou and Audre Lordre
}

\author{
Agung Suhadi, Kiagus Baluqiah, Yupika Mariansyah \\ Muhammadiyah University of Bengkulu \\ agungketupat@yahoo.com
}

\begin{abstract}
This paper explores the construction of feminist thought as portrayed in selected poems of black female writers, Maya Angelou and Audre Lordre. Both writers reveal themes of powerless female protagonists (black African-American women) who undergo mental conflicts as a result of the hegemonic culture in their poetry such as "Phenomenal Woman," "Still I Rise," "On the Pulse of Morning," "Equality," "Woman Work," "Cage Bird," "Remembrance," "A Woman Speaks," "For Each of You," "Love Poem," "Power," "Inheritance," and "Sisters in Arms." By using the concept of feminist criticism, this study shows the forms of hegemonic culture through marginalization, stereotypes, subordination, and oppression. The silence and passivity of female protagonists are seen as active when viewed using this paradigm of female silence (a feminist criticism) because the silence and passivity are strategies used by female protagonists to resist the oppressive social roles, survive, and eulogize the self-accepted of female protagonists from the dominant culture. In conclusion, Maya Angelou and Audre Lordre's seem to exalt the suffering, sacrificing, submissive wife, since it is through these qualities that they will not only survive but finally triumph. These ways encourage the female protagonists (black African-American women) to construct the self-consciousness, black women culture, and identity. In short, these reflect concern over the author's minds and explicitly represent feminist thought.
\end{abstract}

Keywords: feminist thought, powerless, hegemonic culture, black African-American women, and silence and passivity.

\section{INTRODUCTION}

The feminist thought is a notion for struggling the rights of women. This thought has emerged since the early 18 th century due to the women's movement that sued and criticized mistreatments, inequity, exploitation, violence and oppression by men. Echols (1989) argued that the aim of feminist thought is for "reordering society." This advocates equal rights in all aspects of life socially, politically, personally, and professionally. Similarly, as stated by Millett (1971) in Sexual Politics, this thought purports to be concerned with the equality for women. She promoted a number of things on the grounds of equality for women. Furthermore, feminists' tendencies were mainly in opposition to the reform with the adoption of predefined roles for men and women in the private and public spheres. They represent an inappropriate and extreme theory about the same education for both men and women and the same social roles for both sexes not compatible with human nature (Alice, 2002). Feminists insist on the rejection of the role of women as mothers and wives as their duty.
Generally, these bunch of feminists gives fewer values to home and family unless the basis is female.

Writers advocating this thought believe that all enjoyment and growth belong to men and all backward to women. According to feminist thought, women are free to define or live in any format of family structures, including nuclear family and marriage. To oppose against all of the cases above, feminists believe in using available recent legal and political opportunities to change the situation, provide equal economic opportunities, change in family and school, and send mass media message.

These thoughts influence contemporary writers who use their poems as media to spread their beliefs. Maya Angelou and Audre Lordre are among such writers who address women's suffering and painful lives in their poems. Therefore, this study explores their thoughts and is concerned with the main investment for writing; basically, if there is no concern, there will not be a creation of any work of arts or fiction. The how and why of feminist concern, the dominant elements played by both writers-Maya Angelou and Audre Lordre--are the questions on which this study is based. Some scholars have studied Maya Angelou and Audre Lordre's poems in different angles of politic, marginalization, identity, which indicates that there are still many complexities in their poems. This study would like to re-exam how both writers explore their women from selected poems.

\section{METHOD}

This study is qualitative descriptive with textual analysis by conducting comparative criticism as a way to criticize both writers' poems. Comparative criticism is a kind of comparative world view which transcends national, geographical, lingual boundaries, and considers literature as a global phenomenon of human nature. Comparative literature is important because it reveals sources of intellectual and art current and because each literary current on the first contact with global literature helps human consciousness or ethnic orientation. Comparative history studies international literary relationships; it studies common elements in various literature as well (Radfar, 2006). In comparative literature based on the unity of human thought, it can be realized how a thought in one part of the world is represented by a writer, a scholar and someone that appears in another way in another part of the world.

The data of this study were the selected poems of both writers which highlight on the thought of feminism. 
Detail analysis will be supported by some particular ideas of feminists such as Shulamith Firestone and Simone de Beauvoir.

\section{FINDINGS AND DISCUSSION}

Feminist thought in Poems of Maya Angelou and Audre Lorde Maya Angelou and Audre Lordre are the most famous African-American authors of the 20th century. They speak on behalf of their and other African-American slaves who suffered during the black civil war. Many of their work are considered as autobiographies because they contain many of their experiences as African-American women. They further gave a great influence in the field of literature as women's activists and because of that, they received various awards associated with what they had done as feminist activists. Both writers employ similar styles and forms to express the feminist thought as practiced in their selected poems; the women are being victimized or oppressed by male dominated culture, but they also present them as survivors, even when they were being oppressed.

\section{Black Women and Oppression}

Maya Angelou was a black writer who employed her poems as a means of capturing black women who are being oppressed due to white dominating ideology. She exposes the description of African-American women cultural status under white-centered society; they are frequently prevented from being fully accepted by mainstream culture. Her women are in-between of hegemonic culture or keeping their mother culture. They were forced to separate from their mother culture and identify with the new culture. As a result, their cultural identity was threatened, distorted, and brought to the inferior position.

As described in poems "Phenomenal Woman", 'Still I Rise", and "On the Pulse of Morning", Angelou depicts negative stereotypes and bad oppression toward black women through a dual interaction of cultures. This can be seen in "you may write me down in history/with your bitter, twisted lies", exposes the slavery history in the past still embeds a negative image for the black community, particular women. The usage of "bitter"/"twisted" symbolizes a lower status, and their existence in the land of native society is still regarded as "alien" or "others". Angelou further describes black women have to face the odds of life, the lowest living condition, and they can not avoid being influenced by the dominant white cultural values that define the white as superior, good and beautiful, while black as ugly; "you may tread me in the very dirt/but still, like dust".

The situation seemingly brings the life of black women underdetermination of white society that is full of struggle, losing every touch, deprived of access to have a chance as a human being. Maya Angelou reveals through cross-excerpts in her poems "equality" and "remembrance", as follows;

Cause I laugh like I've got gold mines

Diggin' in my own back yard
You may shoot me with your words

You may cut me with your eyes

you may kill me with your hatefulness

From the excerpt above, Angelou vividly describes an agony for African women in all aspects of life. The bitterness of being treated unfairly is clearly depicted with a satirical tone in "shoot me with your words/cut me with your eyes/kill me with your hatefulness". This does not only infuse inferiority acceptance, subaltern culture but demonstrates a hegemonic culture of white society. Besides that, Angelou presents inequality in employment that is being faced as a result of racial and marginal identity for Africans women. They are deprived of their rights to pursue happiness, wealth, and equality through a higher position in jobs. Angelou exposes it in "Woman Work" that black women are forced to do a labour or lowest job. She declares that her women "Is she a robot or a human?/we have no time to stand and stare" reflects black women are in domestic area, they are not only forced to attend the children, husband, other family members but should perform their duties as a gardener, sweeper and caretaker as well. This is a big burden that should be undergone by black women due to their skin colour and racial prejudice.

Thus, as has done by Maya Angelou, Audre Lorde also speaks in her poems to what it is like to belong to her community, that is oppressed women. Lorde takes a big responsibility to expose such discrimination over black women entirely. She gives a description of black women that should be respected as a human being. In fact, her status as women is still not accepted yet due to discrimination from the alien land. Lorde speaks in her "A Woman Speaks" as described below;

moon marked and touched by sun,
It will leave my shape behind.
I seek no favor,
permanent as my errors
I have been woman
for a long time
I am treacherous with old magic
and the noon's new fury
with all your wide futures
promised I am woman
and not white.

She satirically and ironically attacks the discrimination of white community toward her woman. The words like "moon" and "sun", "I will leave my shape behind", "I seek no favor", "permanent as my errors" are kinds of personal and social oppression that black woman experiences for their status as a secondary position of the dominated culture. Lorde also stresses it in her "For Each of You", the suffering and oppression that are faced by the black community, "remember whatever pain you bring back from your dreaming/you are offspring of slave/you mother was a princess in darkness". Furthermore, her poems "Coal" and "Power", implicitly give her voice to racial injustice that allows women to be treated 
unfairly, sometimes brutally. Some excerpts "I am the total black, being spoken from the earth's inside", to separate women selves from "the total black," indicate that their true selves are not necessarily within that "total black, the coal is the outer from and from the coal, from the darkness the diamonds and lights come into being." This asserts and celebrates her blackness, which reflects her personal relationship with the society. Meanwhile, the word "power" shows that woman is searching for power; she has as an African-American women cursed racial injustice practiced in her society.

Black Women and Strong Individuals

Here, Maya Angelou and Audre Lorde indeed present their women survivors as being oppressed by white-dominated culture. They argue that women need to bring their whole selves to the movement and they believe that difference, diversity, and inclusion should be the lifeblood of the feminist movement. These writers remind us that women are not only victimized because of their race but sex as well. For instance, in the late 70 s and early 80 s, there was a rash of brutal rapes and murders of black women, mostly in the Boston area. As stated in the Need: A Chorale of Black Women's Voices, Lorde articulates race and sex in the victim's experience, she stands on the fringes of society and is, therefore, able to see injustice more clearly. She also stands on the outskirts of the white women's movement and is able to critique it in a way what that holds it accountable and calls it on its broadest and truest ideals-the thinking being and in her own words in order to create an identity in terms of race, discrimination, and sex.

Maya Angelou is a very influential voice to the complicity of racial equality, gender, and femininity. Most of her poems mirror the strong and powerful identity as a woman, and even more importantly as the black woman. Lupton (1998) argued that Angelou is still regarded as a potential feminist due to her awareness of the destructive force working against her society (72). As described in poems "Still I Rise", "Phenomenal Woman", "Caged Bird", besides vividly delivering racial and oppression issues, she defines the "self" of black American female very impression. The self becomes shaped after what has been experienced through life. The use of "I" means self as a black American female, who is being oppressed and against all odds to rise and celebrate her integrity. In "Still I Rise," black American women claim that they should have the rights and freedom toward what they want to be. The self should not be esteemed in physical appearance or gender, rather than human equality. Through historical events, black American women desire to be independent as asserted by Angelou's word "to rise", from all the suffering and subjugation. This is similar to what is reflected in "Phenomenal Woman": "I'm not build to suit a fashion model size", which asserts directly self-assured inner self, "the curl of my lips/the sun of my smile/the span of my hips/it's in the fire in my eyes," which symbolizes and illustrates a powerful, very confident woman. Similarly, the portrayal of life of African-American women is presented in the poem "Weekend Glory," where a woman says: "my job at the plant/ain't the biggest bet/but I pay my bills/ and stay out of debt", the notion that there is a protest and "something coming" at the end of the day is presented in the lines: "I get my hair done/for my own sake" and then goes "to my friend girl's house/where we plan our round". In this poem, there is always the untold secret that was once revealed to the white world and that will bring out changes or will have an impact on everybody's future lives.

Furthermore, Audre Lorde exposes for the brave and strong individuals among the enslaved African-American $\mathrm{s}$ women who have managed to have freedom and space to the coming generation. Lorde's awareness of reinvention toward her women is strongly connected with the idea of physical beauty that is understood by white American women as being one the best virtues. She is aware that black women in American society in the mother-daughter's relationship is complicated by racism and the history of black. She is with silence and attempts to protect their life from the realization of it. Her "A Woman Speaks" conveys woman's gender role in society. She notices many injustices that are spoken to the black women experience. She argues for the experience of being women in intimate detail, making the themes of motherhood and womanhood. This shows that feminist trends in Lorde are much stronger than in Sexton, and Lorde can be called a feminist writer but not Sexton. While in the poem power, Lorde reacts to white oppression. This comes from a real experience in which she reacted to the acquittal of a white police officer who shot and killed a ten-year-old black child. She asserts that "my mouth splits into dry lips/without loyalty or reason/thirsting for the wetness of his blood" illustrates to explain the experience of being lost in the sea of white oppression. She feels lost in a white desert. The only fluid in the desert is the blood of a dead black child. Lorde has no reason to thirst for this fluid; she has no loyalty to white dominance. Besides that Lorde describes how the lone black juror was "convinced" by the eleven white jurors. This demonstrates the power of white influence and authority:

They convinced me" meaning

they had dragged her black Woman's frame

over the hot coals

of four centuries of white male approval

Lordre says she must learn how to deal with her rage. If she does not, her rage might cause her to act in the same violent and oppressive ways she is criticizing: "But unless I learn to use/the difference between poetry and rhetoric/my power too will run corrupt as poisonous mold", demonstrates the corrupting potential of power. She also shows how power is used in oppression, how it is used in rage and retaliation, and finally, how it might be used to work against powerful and oppressive entities.

These women are conscious here for getting a lot of changes in their lives. This group treatment potentially renders each individual African-Americans women invisible as a full human. These ways of life have found wide support among them. Some changes can also occur in the private, personal space of an individual black women's consciousness. Black 
women become "smarter" to deal with their problem regarding the discrimination of color and gender. As black women consciousness arises, they need the power to be free from the gender and race discrimination that happen to them. As stated by Collins (2000) in her book:

U.S. black women intellectuals have long explored this private, hidden space of black women's consciousness, the "inside" ideas that allow black women to cope with and, in many cases, surpass the confines of intersecting oppressions of race, class, gender, and sexuality (p. 98).

\section{Black Women Writers and Feminism}

This study has set out to examine how the concepts adapted by feminists are used to analyze Maya Angelou and Audre Lorde's poems. Both black writers depict women as being strong mentally and confident sexually, even though suppressed, oppressed due to the domination of white-centered society. This study also examines the extent to which Maya Angelou and Audre Lorde reinforces or challenges stereotypical representation of white center society as practiced in the selected poems of Maya Angelou and Audre Lorde. The stereotypical representation of black women as the weaker gender has been challenged and given a new perspective by both black writers as strong and capable women.

\section{CONCLUSION}

This study has set out to examine how both writers employ the feminist thought in their selected poems. They have resisted portraying their women as weak, submissive, and powerless women in the poems. They have cleverly developed their women as strong, capable and daring individual. By doing so, they have made readers reflect on the current social and cultural norms, and to challenge, renew and redefine practices, which have become part of our lives. Dominated practices by men, that has long "shackled" women and subjugated them, have been brought to scrutiny by these poems. Maya Angelou and Audre Lordre link the feminists thought of "freedom" into perspective and highlight the socially construed and constructed gender roles and the biases that come with them in contrast to the contemporary women who seek independence.

\section{REFERENCES}

Angelou, M. (1994). The complete collection poems of Maya Angelou. New York: Random House, Inc.

Awkward, M. (1995). Negotiating difference: Race, gender, and the politics of positionality. University of Chicago Press.

Collins, P.H. (2000). Black feminist thought: Knowledge, conciousness, and the politics of empowerment. ( $2^{\text {nd }}$ ed.). New York, NY: Routledge.

Davis, A.Y. (1983). Women, race \& class. New York: Random House, Inc.

DeGout, Y.Y. (2009). The poetry of Maya Angelou: Liberation ideology and technique. In H.Bloom (Ed.), Bloom's Modern Critical Views -Maya Angelou (pp.110125). New York: Infobase Publishing.
Echols, A. (1989). Daring to be bad: Radical feminism in America 1967-1975 (American culture. Minneapolis: University of Minnesota Press.

Evans. M. (1984). Black Women Writers (1950-1980). A Critical Evaluation. Achor.

Guerin, W.1.et al. (Eds.). (2004). A handbook of critical approaches to literature. Beijing: Foreign Language Teaching and Reseach Press.

Hagen, L.B. (Ed.). (1997). Heart of a woman, mind of a writer, and soul of a poet: A Critical analysis of the writings of Maya Angelou. Lanham: University Press of American, Inc.

Lupton, M.J. (1998). Maya Angelou: A critical companion. Westport, Connecticut: Greenwood Press.

Lorde, A. (1978). The black unicorn, Toronto: George T. MC Lead Ltd.

Millet, K. (1971). Sexual politics. Granada: Granada Publishing.

Steady, F.C. (1981). The black woman cross-culturally: An overview. Cambridge, MA: Schenkman.

Radfar, A. (2006). Modern Persian literature compared with comparative literature. International Journal of English and Literature, 1(4), 214-226. 